\title{
EFFECT OF BISPHENOL A ON CORPUS EPIDIDYMIS AND CHROMOSOMAL PATTERN OF ADULT RATS
}

\author{
Abdelmonem Awad Hegazy ${ }^{1}$, Ahmed M. A. Omar ${ }^{2}$, Youssef Hussein ${ }^{1}$, Maha M. Abdul Rahman ${ }^{1}$, Emtethal M. \\ El-Bestawy ${ }^{1^{*}}$ \\ ${ }^{1}$ Anatomy and Embryology Department, \\ ${ }^{2}$ Forensic Medicine and Clinical Toxicology Department, \\ Faculty of Medicine, Zagazig University, Zagazig, Egypt
}

* Correspondence: E-mail: emelbestawy@gmail.com; Cell phone:

$+201024232128$
Introduction: The epididymis is a male accessory organ essential for male fertility. The biochemical and physiological consequences of genotoxicity which are of most concern are the effects on the reproductive health. Bisphenol A (BPA) is a chemical used in the production of polycarbonate plastics and epoxy resins. It is present in food and drink packages. It is considered an endocrine disrupting factor due to is estrogenic properties.

Aim of the Work: The study aimed to demonstrate the possible changes in the corpus epididymis structure and chromosomal pattern following administration of BPA.

Materials and Methods: Thirty-six adult male albino rats were used; and divided into three groups: Group I (control); each rat received $1 \mathrm{~mL}$ corn oil once daily. Group II (BPA treated); each rat was given BPA in corn oil in a dose of $50 \mathrm{mg} / \mathrm{kg}$ orally once daily for 8 weeks. Group III (follow-up); the rats of this group were given the same dose for the same duration as group II then held for another 4 weeks without BPA administration. At the end of experimental period, blood was collected for serum testosterone assessment. Histological and immunohistochemical investigations were done on epididymis; and the femoral bone was used for cytogenetic studies.

Results: Light microscopic examination of corpus epididymis in treated group revealed wide intercellular and intertubular spaces with inflammatory infiltration and blood vessels congestion. The tubules were empty or filled with cellular debris. The epithelial lining showed vaculation, darkly stained nuclei and stratification. The abnormal sperm forms and both the structural and numerical chromosomal aberrations were significantly increased. These parameters were improved in follow-up group but not reached the levels of control one.

Conclusion: BPA administration could induce histopathological changes in corpus epididymis associated with genotoxic effects. These changes were partially reversible after stoppage of administration.

Key words: Bisphenol A; Corpus epididymis; Epididymal sperm; Chromosomal aberration

\section{INTRODUCTION}

$\mathbf{T}$ The epididymis is a male accessory organ that lies in the scrotum related to the testis. It is not just a channel for sperm transport but it has an active contribution in formation of a fertile ejaculates ${ }^{[1]}$. Epididymis can be a target for different toxicants. Epididymal toxicity affects sperm maturation and hence the fertility of individuals ${ }^{[2]}$.

Chromosomes determine traits of an individual through the transmission of specific genetic information from both parents [3]. The biochemical and physiological consequences of genotoxicity which are of most concern are the effects on the reproductive health which include gamete 
loss, reduced fertility, embryo mortality and malformation ${ }^{[4]}$.

BPA is a synthetic polymer used in the production of epoxy resins and polycarbonate plastic. The resins are used to coat metal product such as food cans, bottle tops and water supply pipes while the polycarbonate plastics are involved in food and drink packaging. Some polymers that contain BPA are used in dental sealant and tooth coating ${ }^{[5]}$. Trace amounts of BPA released from these products could lead to human exposure. Thus in human, it was detected not only in serum and urine but also in saliva, placenta and amniotic fluid; and measurable blood levels of BPA were detected in human fetuses ${ }^{[6]}$.

BPA is considered a major endocrine disrupting chemical being a "selective estrogen receptor modulator" ${ }^{[7]}$. It also has a weak anti-androgenic activity; it directly binds to the androgen receptor at higher doses than required for the estrogen receptor, and reduces testosterone levels via its effects on the testis ${ }^{[8]}$.

Conflicting results have been yielded by studies of BPA genotoxicity ${ }^{[9,10]}$. In addition, BPA was found to have toxic effects on the caput and cauda ${ }^{[[11,12]}$ epididymis. No previous studies were available regarding the effects of BPA on the corpus epididymis

The aim of the present work was to demonstrate the possible changes that take place in the corpus epididymis structure and chromosomal pattern of adult male albino rats after administration of BPA and to assess the possibility of recovery after stoppage of drug administration.

\section{MATERIALS AND METHODS}

Thirty-six adult male albino rats were used. They were divided into three groups each contains 12 rats. Group I (control group): Animals received $1 \mathrm{~mL}$ corn oil orally by gavage once daily for 8 weeks. Group II (BPA treated group): Rats were given BPA powder (B37880, Alpha Chemika, Mumbai, India) dissolved in corn oil as a daily oral dose of 50 $\mathrm{mg} / \mathrm{kg}$ body weight by a gastric tube for 8 weeks ${ }^{[13]}$. Group III (follow up): Animals were given the same dose for the same duration as group II then held for another 4 weeks without
BPA administration. At the end of experimental period, half of the rats were anesthetized using ether inhalation and the epididymides were removed and processed for histological and immunohistochemical study. The other half of rats was used for cytogenetic study.

\section{Histological study}

Each right epididymis was immediately immersed in $10 \%$ formol saline for 48 hours to be processed and embedded in paraffin ${ }^{[14]}$. Five um thick sections were prepared and stained with haematoxylin and eosin $(\mathrm{H} \& \mathrm{E})$ and Masson's trichrome stain ${ }^{[15]}$.

\section{Immunohistochemical study immunoreactivity)}

(BAX

It was performed using the avidin biotin peroxidase system for localization of BAX. The primary antibody used was delivered from Sigma Laboratories (Code No. B8429). Universal kits used the avidin biotin peroxidase system were produced by Novacastra Laboratories Ltd. in UK. Mayer's Haematoxylin was used as a counterstain. Positive immunoreaction was indicates by the brown cytoplasmic staining ${ }^{[16]}$.

\section{Image analysis and morphometric study}

The tubular diameters, epithelial cell heights and area percent of BAX immunoreaction were measured using image analyzer computer system in Department of Pathology, Faculty of Dentistry, Cairo University.

\section{Epididymal sperm examination}

Spermatozoa collection from the left epididymis was done ${ }^{[17]}$. The cauda epididymis of each rat was cut and squeezed gently to get the fresh undiluted semen in a clean Petri dish to do the following examinations; Sperm count, motility, viability and morphology ${ }^{[18-20]}$.

\section{Serological study}

Blood was collected using micro-capillary glass tubes under light ether anesthesia. Serum testosterone hormone has been measured by enzyme-linked immunosorbent assay (ELISA) [21]

\section{Cytogenetic study}

Cytogenetic study was performed using bone marrow technique ${ }^{[22]}$. The slides were examined using oil immersion lens of an ordinary light microscope. One hundred metaphases were examined in each rat for 
numerical and structural chromosomal abnormalities.

\section{Statistical analysis:}

Statistical analyses were done using SPSS software (version 19). Data were arIIanalysis of variance (ANOVA) ( $\mathrm{F}$ test) and LSD test. $\mathrm{P}$ value $<0.05$ was considered significant.

\section{RESULTS \\ I- Histological examination}

The tubules of the corpus epididymis of the control group were lined by pseudostratified epithelium with stereocilia. The epithelium constituted of columnar principle cells, basal cells (flat) and clear cells with pale cytoplasm (Fig. 1-A).

In BPA treated group, the tubules were empty; and others contained cellular debris with few sperms. Intertubular spaces were wide and contained inflammatory cells. The epithelial lining of the tubules showed vaculations, wide intercellular spaces and stratification, (Figs. 1-B, C). The epithelial cells had darkly stained nuclei. Halo cells were frequent and displaced towards the lumen. Clear cells were less frequent and mostly absent (Fig. 1-D). The basement membrane was detached in some tubules (Fig. 1-E).

In the follow-up group, the sperms were present in the tubules. The intertubular spaces were less wide than that in the treated group (Fig. 1-F).

\section{Masson trichrome stained sections}

Sections of the corpus epididymis showed little collagen fibers in the control group (Fig. 2-A). Excessive collagen fibers were seen in the treated group (Fig. 2-B). In the follow-up group, little collagen fibers were observed (Fig. 2-C).

Immunohistochemical study to $B A X$

Faint positive immunoreaction for BAX was showed in the control group (Fig. 2-D).
Strong positive reaction to BAX, in nearly all epithelial cells, was observed in the treated group (Fig. 2-E). In the follow-up group, a weak positive reaction was seen (Fig. 2-F).

\section{II- Morphometric and statistical study}

The oral administration of BPA induced a very high statistical significant decrease in the tubular diameter and epithelial cell height and increase in area percent of BAX immunoreactions when compared to the control group. A very high significant increase in tubular diameter and epithelial cell height and decrease in area percent of BAX immunoreactions were observed in the follow up group in comparison with the treated group (Table 1).

\section{III- Epididymal sperm analysis}

BPA-treated group showed a very highly significant decrease in sperm count, viability and motility with an increase in the abnormal forms when compared to the control group. A highly significant increase in sperm count, viability, motility and decrease in the abnormal forms was recorded in the follow up group when compared to the treated group (Table 2).

\section{IV-Serological study}

The oral administration of BPA induced a very high statistical significant decrease serum testosterone level when compared to the control group. A high significant increase in the mean values of serum testosterone level was recorded in the follow up group when compared to the treated group (Table 2).

\section{V- Cytogenetic study}

BPA-treated group showed a very high statistically significant increase in the chromosomal aberrations compared to the control group. A significant decrease in the chromosomal aberrations was recorded in the follow-up compared to the treated group, but not reached the levels of controls (Table 3). 


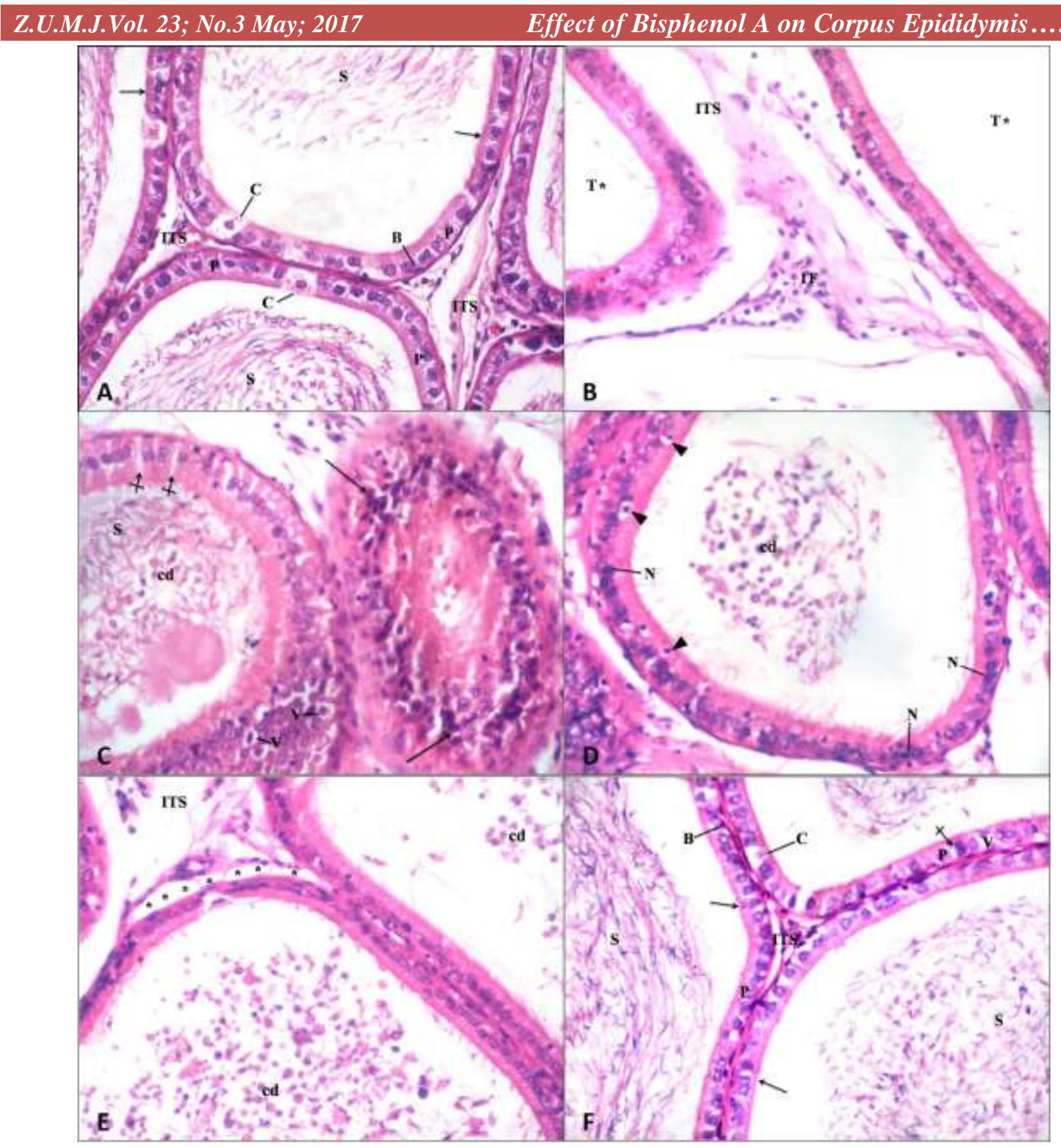

Fig. (1): Photomicrographs of H\&E sections (X 400) in the corpus epididymis of an adult male albino rat of the control (A), BPA treated (B, C, D, E) and follow up (F) groups showing A: The pseudostratified epithelial lining of the tubules with stereocilia (arrow), Principal cells (P), basal cells (B), Clear cells (C), Sperm in lumen (S) and narrow intertubular spaces (ITS); (B) Inflammatory infiltration (IF) in the wide intertubular space (ITS) and empty tubules ( $\mathrm{T}^{*}$ ); (C) Tubule with stratification of the lining epithelium (arrow), another tubule with few sperms (S) and cellular debris (cd) in lumen, vaculations of the epithelial cells (V) and wide intercellular spaces (crossed arrow); (D) Epithelial cells with darkly stained nuclei (N) lining the tubules. Halo cells are displaced toward the lumen (arrow head). The tubules contain cellular debris (cd). Clear cells are not observed; (E) Tubules with cellular debris (cd) in lumen, detached basement membrane (asterisk) and wide intertubular space (ITS); (F) The pseudostratified epithelial lining of the tubules with stereocilia (arrow), vaculation (V) of the epithelial cells, wide intercellular spaces (crossed arrow), sperms (S) in lumen, less wide intertubular space (ITS), principal cells (P), basal cells (B) and clear cells (C). 


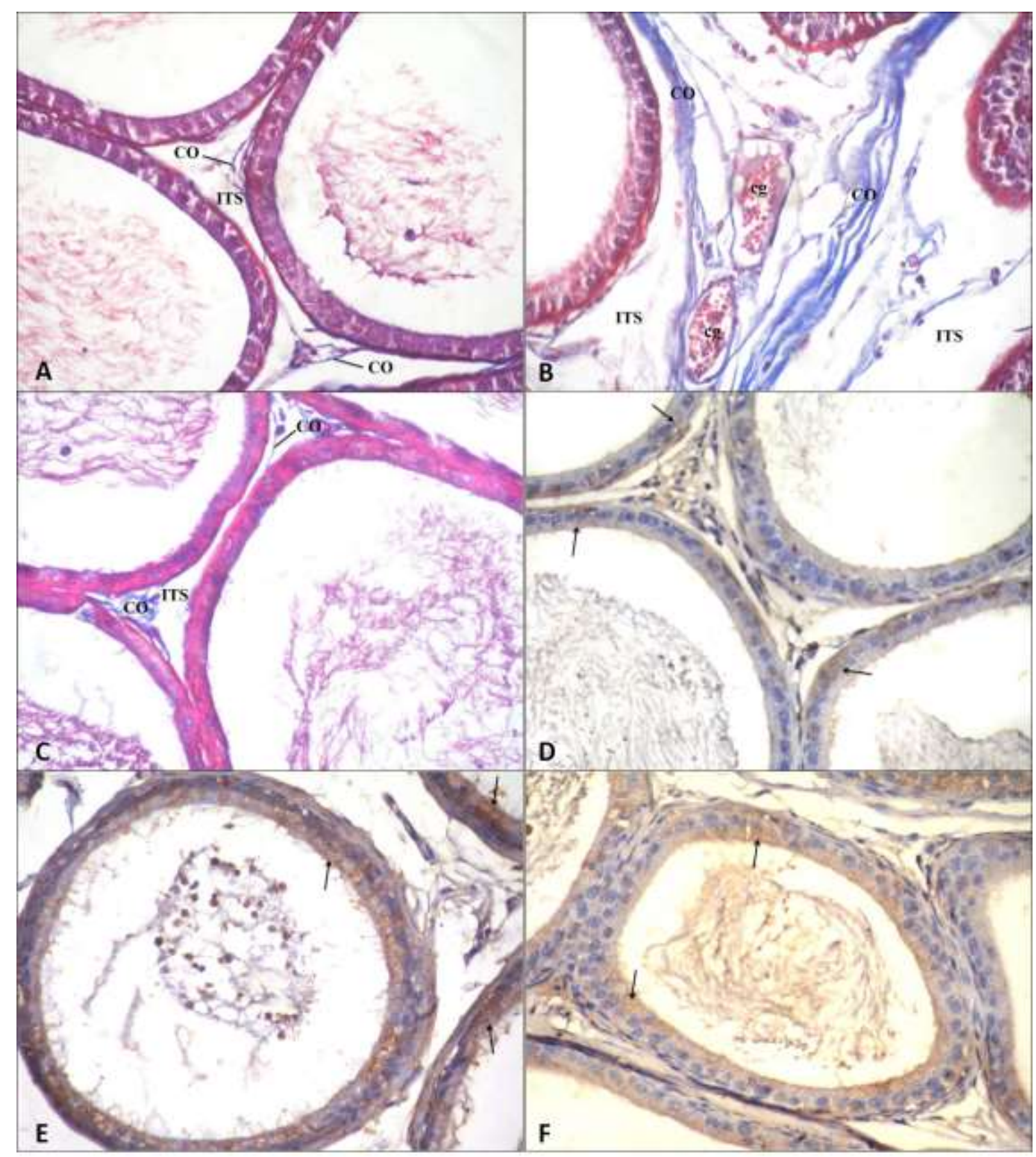

Fig. (2): Photomicrographs (A,B,C) of Masson trichrome stained sections (X 400) in corpus epididymis of an adult albino rat of the control (A), BPA-treated (B) and follow-up (C) groups showing: (A) Little blue stained collagen fibers (CO) in the intertubular space (ITS); (B) Excess blue stained collagen fibers (CO) in the intertubular space (ITS) and congested blood vessels (cg); (C) Little blue stained collagen fibers (CO) in the intertubular space (ITS).

Photomicrograph (D,E,F) of BAX immunoreaction (X 400) in corpus epididymis of an adult albino rat of the control (B) BPA-treated (C) and follow-up (D) groups showed: (D) Faint positive immunoreaction for BAX in the cytoplasm of the epithelial cells lining the tubules (arrow); (E) Strong positive immunoreaction for BAX in the cytoplasm of nearly all the epithelial cells lining the tubules (arrow); (F) Weak positive immunoreaction for BAX in the cytoplasm of the epithelial cells lining the tubules (arrow). 


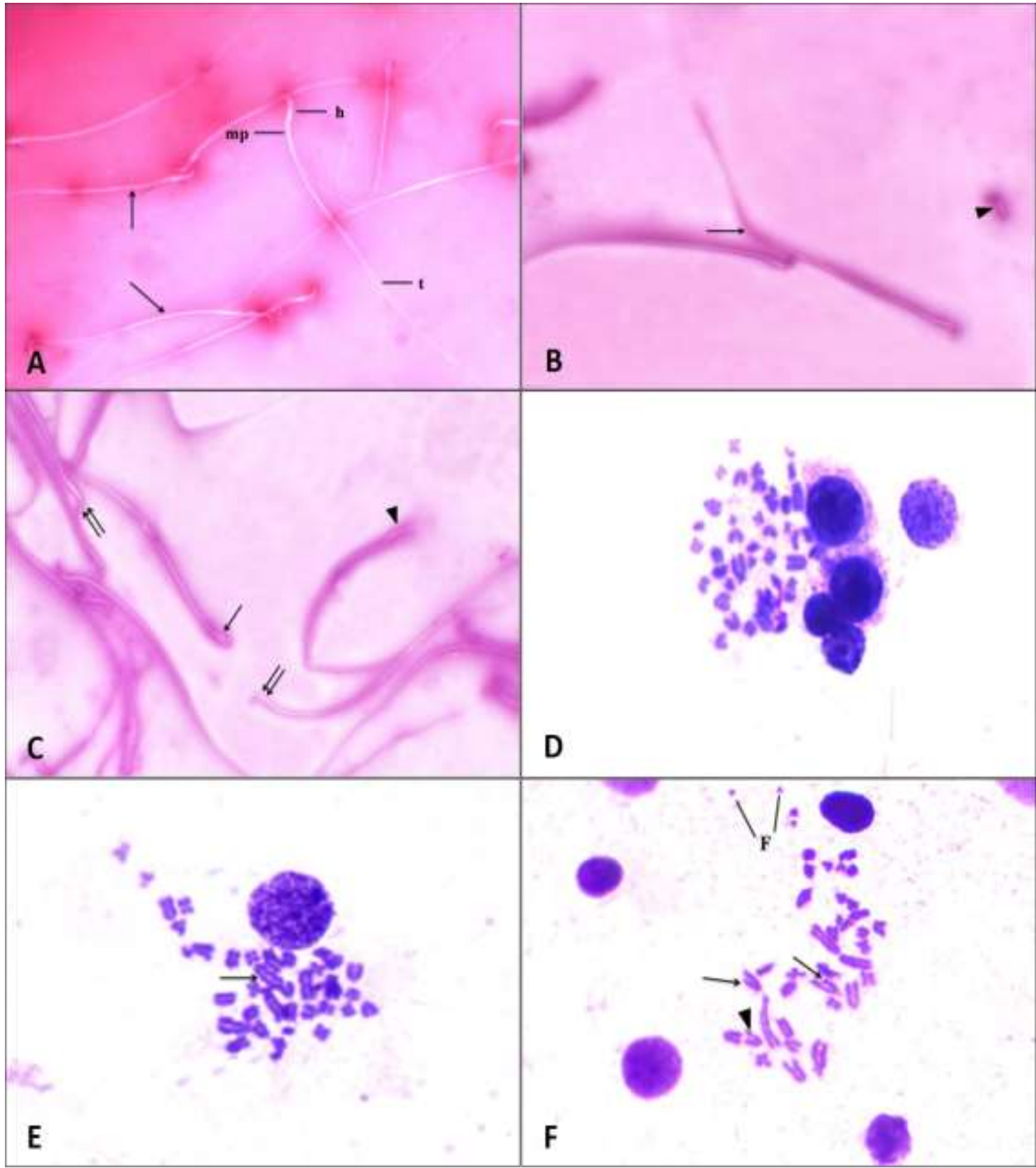

Fig. (3):

Photomicrographs (A,B,C) of Nigrosin and Eosin stained smears (X 400) obtained from a sample of semen of adult male albino rat of the control (A), BPA-treated (B) and follow-up (C) groups showing: (A) Normal live sperm (not stained) (arrow) and parts of normal sperm; hook shaped head (h), midpiece (mp) and tail (t); (B) Abnormal dead sperm with kinked tail (arrow) and a detached head (arrow head); (C) Two abnormal dead sperm, one with amorphous head (arrow) \& the other with banana head (arrow head) and two live sperm (double arrow).

Photomicrographs (D,E,F) of a metaphase spread (Giemsa X 1000) prepared from the bone marrow cells of an adult male albino rat of the control (D), BPA-treated (E,F) showing: (D) Normal chromosomal pattern; (E) Dicentric chromosome (arrow); (F) Terminal chromatid deletion (arrow), a chromosome with break (arrow head) and chromosomal fragments (F). 
Table 1: Means \pm SD of tubular diameter, epithelial cell height and area percent of BAX immunoreactions in different groups

\begin{tabular}{cccccc}
\hline Group & Control & BPA Treated & Follow Up & F & P \\
\hline $\begin{array}{c}\text { Epithelial cell height } \\
(\mathbf{u m})\end{array}$ & $36.80 \pm 2.27$ & $20.73 \pm 1.63$ & $28.11 \pm 1.57$ & 117.65 & $\mathrm{P}<0.001$ \\
\hline $\begin{array}{c}\text { Tubular diameter }(\mathbf{u m}) \\
\text { Area percent BAX }\end{array}$ & $247.36 \pm 1.48$ & $174.00 \pm 4.20$ & $201.60 \pm 2.23$ & 989.81 & $\mathrm{P}<0.001$ \\
\hline $\begin{array}{c}\text { Ammunoreactions } \\
\text { imm }\end{array}$ & $25.39 \pm 6.50$ & $79.72 \pm 12.49$ & $51.12 \pm 13.65$ & 57.39 & $\mathrm{P}<0.001$ \\
\hline
\end{tabular}

Table 2: Means \pm SD of serum testosterone level and sperm parameters in different groups

\begin{tabular}{cccccc}
\hline Group & Control & BPA-Treated & Follow Up & F & P \\
\hline Testosterone (ng/ml) & $3.42 \pm 0.32$ & $1.46 \pm 0.68$ & $2.64 \pm 0.27$ & 27.02 & $<0.001$ \\
\hline Sperm count (million/ml) & $85.21 \pm 4.18$ & $42.20 \pm 1.92$ & $68.50 \pm 2.50$ & 307.12 & $<0.001$ \\
\hline Viability (\%) & $91.00 \pm 2.82$ & $40.66 \pm 3.50$ & $72.33 \pm 1.96$ & 482.90 & $<0.001$ \\
\hline Motility (\%) & $84.16 \pm 1.47$ & $36.50 \pm 3.01$ & $65.83 \pm 2.31$ & 237.17 & $<0.001$ \\
\hline Normal forms (\%) & $94.33 \pm 1.21$ & $63.33 \pm 3.98$ & $80.33 \pm 1.36$ & 225.93 & $<0.001$ \\
\hline Head abnormalities & $2.16 \pm 0.98$ & $14.83 \pm 0.40$ & $8.50 \pm 1.04$ & 323.28 & $<0.001$ \\
\hline Midpiece abnormalities & $1.33 \pm 0.51$ & $4.83 \pm 0.75$ & $2.16 \pm 0.75$ & 42.97 & $<0.001$ \\
\hline Tail abnormalities & $2.33 \pm 1.21$ & $13.83 \pm 1.9$ & $9.00 \pm 1.67$ & 74.71 & $<0.001$ \\
\hline
\end{tabular}

Table (3): Means \pm SD (Range) of chromosomal aberrations in the bone marrow cells of the adult male albino rats in different groups.

\begin{tabular}{|c|c|c|c|c|c|}
\hline Group & Control & BPA-treated & Follow Up & $\mathbf{F}$ & $\mathbf{P}$ \\
\hline Chromosomal Break/gap & $\begin{array}{c}0.66 \pm 0.51 \\
(0-1)\end{array}$ & $\begin{array}{c}4.50 \pm 1.04 \\
(3-6)\end{array}$ & $\begin{array}{c}3.1 \pm 0.75 \\
(2-4)\end{array}$ & 35.25 & $<0.001$ \\
\hline Terminal chromatid deletion & $\begin{array}{c}0.83 \pm 0.75 \\
(0-2)\end{array}$ & $\begin{array}{c}7.16 \pm 1.47 \\
(5-9)\end{array}$ & $\begin{array}{c}4.80 \pm 0.75 \\
(4-6)\end{array}$ & 55.96 & $<0.001$ \\
\hline Chromosomal fragment & $\begin{array}{c}1.50 \pm 0.83 \\
(1-3)\end{array}$ & $\begin{array}{c}10.50 \pm 1.04 \\
(9-12)\end{array}$ & $\begin{array}{c}7.33 \pm 1.03 \\
(6-10)\end{array}$ & 130.87 & $<0.001$ \\
\hline Ring chromosome & $\begin{array}{c}0.33 \pm 0.51 \\
(0-1)\end{array}$ & $\begin{array}{c}4.66 \pm 1.03 \\
(3-6)\end{array}$ & $\begin{array}{c}3.0 \pm 0.89 \\
(2-4)\end{array}$ & 40.31 & $<0.001$ \\
\hline Dicentric chromosome & $\begin{array}{c}0.16 \pm 0.40 \\
(0-1)\end{array}$ & $\begin{array}{c}6.50 \pm 1.04 \\
(4-8)\end{array}$ & $\begin{array}{c}3.16 \pm 1.16 \\
(2-5)\end{array}$ & 68.60 & $<0.001$ \\
\hline Clumping & $\begin{array}{c}1.60 \pm 0.81 \\
(1-3)\end{array}$ & $\begin{array}{c}10.33 \pm 1.63 \\
(8-12)\end{array}$ & $\begin{array}{c}7.80 \pm 1.47 \\
(6-10)\end{array}$ & 65.12 & $<0.001$ \\
\hline Polyploidy & $\begin{array}{c}0.16 \pm 0.40 \\
(0-1)\end{array}$ & $\begin{array}{c}10.33 \pm 1.03 \\
(9-12)\end{array}$ & $\begin{array}{c}8.33 \pm 1.21 \\
\quad(7-10)\end{array}$ & 193.39 & $<0.001$ \\
\hline Hypoploidy & $\begin{array}{c}0.50 \pm 0.54 \\
(0-1)\end{array}$ & $\begin{array}{c}4.33 \pm 0.81 \\
(3-5)\end{array}$ & $\begin{array}{c}2.33 \pm 0.51 \\
(2-3)\end{array}$ & 53.64 & $<0.001$ \\
\hline
\end{tabular}

\section{DISCUSSION}

The effect of BPA on the caput and cauda epididymis has been studied by El Gazzawy et al. and Mazroa, respectively ${ }^{[11,12]}$. The current study is concerned with the effect on the corpus epididymis.
In the present work, wide intercellular spaces were noticed in the BPA treated group. Oxidative stress is a crucial factor to induce cell-cell dissociation ${ }^{[22]}$. BPA was reported to induce of oxidative stress in the cauda epididymis and other vital organs ${ }^{[12,24]}$. The wide intercellular spaces reflect a probable 
affection of the tight junction between the epithelial cells. Stable and persistent tight junctions can provide the epididymis with resistance to cancer ${ }^{[25]}$. In addition, loss of the tight junction between principle cells leads to disruption of the blood epididymal barrier which is critical for male fertility. It provides immune protection to sperm and suitable luminal media for maturation by controlling exchange between blood and lumen ${ }^{[26]}$.

In this study, halo cells and interstitial inflammatory cellular infiltration were frequently observed in the treated group. The alteration of the barrier components and loss of its function has been associated with a decreased fertility [27]. Moreover, it is accompanied with immune response in the form of an increase in number of macrophages in the interstitium and abnormal halo cells in the epithelium in ${ }^{[28]}$.

The epithelium in the current work showed vaculations and darkly stained nuclei; a picture suggestive of apoptosis. Hughes and Mehmet reported that apoptotic cells shrink with loss normal cell junction ${ }^{[29]}$. High apoptosis could result in azospermia ${ }^{[30]}$.

The statistical analysis in the present study revealed a significant reduction in the epithelial height and decrease of the tubular diameter in the treated group as compared with the control group. These results are in accordance with Mazroa ${ }^{[12]}$.

The tubular lumen in the treated group was found to be either empty or contained cellular debris. The cellular debris appeared mostly to be of testicular origin as the epithelium of those tubules was intact. Kempinas and Klinefelter stated that sloughed germ cells secondary to spermatogenic disturbances or androgen deprivation in the testis are the most common source of cells and cellular debris in the lumen of the epididymis ${ }^{[31]}$.

The biochemical essay results showed a reduction in serum testosterone level in the treated group. Testosterone deficiency has been found to cause blockade in conversion of round to elongated spermatids. As a result round spermatids will slough and appear in the lumen. In addition, epithelial apoptosis and reduction in epididymal tubule diameter and epithelial cell height are results of androgen deprivation ${ }^{[31]}$.

Halo cells were frequent and displaced towards the lumen in the treated group. Similar observation was reported by $\mathrm{El}$ Gazzawy et al. in caput epididymis ${ }^{[11]}$. These cells are derived from the immune system and considered migrating lymphocytes due to increase phagocytic activity ${ }^{[32]}$.

Excess connective tissue and collagen fibers were observed between epididymal tubules. Similar observation was reported in cauda epididymis ${ }^{[12]}$.

Clear cells were markedly absent in the treated group. Clear cells are known to take up particulate matter from the luminal compartment ${ }^{[32]}$. Absence of clear cells is a feature of epididymal toxicity ${ }^{[31]}$.

Detachment of the basement membrane was also observed in the present study. The basement membrane provides the epithelial cells with survival stimulus. It controls cell polarization, macromolecular diffusion, sequestration of cytokines, growth factors and regulates both immune response and oncogenic cell invasion ${ }^{[33]}$.

The immunohistochemical study showed positive reaction to $\mathrm{BAX}$ in the treated group. BAX is a cytosolic protein that is responsible for mitochondrial outer membrane permeabilization "MOMP". It is a master effector of apoptosis as death stimuli fail to induce MOMP and apoptosis in cells lacking BAX protein ${ }^{[34]}$. Lin et al. stated that BPA induced apoptosis through the intrinsic mitochondrial pathway ${ }^{[35]}$.

Stratification of the epithelium lining the tubules was reported in the treated group. Haschek et al. stated that squamous metaplasia and stratification of accessory sex organs are a major morphological manifestation of xenobiotics and compounds that have estrogenic activity ${ }^{[36]}$.

The semen analysis of treated group showed increase in the abnormal forms. This is in accordance with results obtained by Karnam et al ${ }^{[37]}$. Morphology of the sperms may be even more important than count or motility in determining potential fertility. Sperm with 
abnormal shape cannot fertilize an egg ${ }^{[38]}$. Significant decrease of the sperm count was reported in the treated group as compared to the control group. This is in agreement with Herath et al ${ }^{[39]}$. However, Howdeshell et al. reported that BPA had no effect on the sperm count ${ }^{[40]}$. The decrease in sperm count can be explained by the anti-androgen character of BPA or oxidative stress ${ }^{[41,42]}$.

The cytogenetic study revealed a significant increase in the numerical and structural chromosomal aberrations in the treated group. These results are in agreement with Vanage et al [9]. Elevated levels of chromosomal aberrations are suggested as an indicator of the early phase of carcinogenesis and considered as a predictive of cancer risk ${ }^{[43]}$.

The follow-up group showed sperms in the tubular lumen and little collagen fibers, but absence of clear cells and weak positive reaction to $\mathrm{BAX}$ were observed. The sperm count and testosterone level showed significant increase but neither reached the base line. Such incomplete recovery following stoppage of BPA was also observed in the testis by Mohamed and Arafa ${ }^{[13]}$.

It was concluded that, BPA could induce a structural hazards in corpus epididymis associated with genotoxic effects. These changes were partially reversible after stoppage of administration.

\section{Acknowledgements}

We acknowledge Scientific and medical research center 'ZSMRC' of Zagazig Faculty of Medicine for its support.

\section{REFERENCES}

1. Turner TT: De Graaf's Thread: The Human Epididymis. Journal of Andrology. 2008; 29(3): 237- 250.

2. Pryor JL, Hughes C, Foster W, Hales BF, Robaire B. Critical windows of exposure for children's health: the reproductive system in animals and humans. Environmental Health Perspectives. 2000; 108(suppl 3): 491-503

3. Sadler, T.W.: Langman's Medical Embryology. 12th ed. Lippincott Williams \& Wilkins. China. 2012: P: 235-243.

4. Nakano E, Tallarico LF: The dominant lethal test in the snail Biomphalaria glabrata: An assay to detection of germ cell mutagens in freshwater for environmental monitoring. In: Valon, C. L. (editor). New Developments in Mutation Research. New York, USA: Nova Science Publishers, Inc, 2006:189-216.

5. Shelby M.D. NTP-CERHR monograph on the potential human reproductive and developmental effects of bisphenol A. National Toxicology Program-Center for the Evaluation of Risks to Human Reproduction. 2008; (22): 1-64.

6. Vandenberg LN, Chahoud I, Heindel JJ, Padmanabhan V, Paumgartten FJR et al. Urinary, Circulating, and Tissue Biomonitoring Studies Indicate Widespread Exposure to Bisphenol A. Environmental Health Perspective. 2010; 118(8): 1055-1070.

7. Kurosawa $\mathrm{T}$, Hiroi $\mathrm{H}$, Tsutsumi $\mathrm{O}$, Ishikawa T, Osuga $\mathrm{Y}$ et al. The activity of bisphenol A depends on both the estrogen receptor subtype and the cell type. Endocrine Journal. 2002; 49: 465-71.

8. Ye L, Zhao B, Hu G, Chu Y, Ge RS. Inhibition of human and rat testicular steroidogenic enzyme activities by bisphenol A. Toxicology Letters. 2011; 207:137-42.

9. Vanage GR, Salian S, Tiwari D, Kamble J, Padwal V et al. Reproductive and Genetic Toxicity Studies of Bisphenol A, an Endocrine Disrupter. Biology of Reproduction. 2008; 78: 227. 734.

10. Naik, P. and Vijayaaxmi, K.K.: Cytogenetic evaluation for genotoxicity of Bisphenol-A in bone marrow cells of Swiss albino mice. Mutatation Research. 2009; 676:106-112.

11. El Ghazzawy IF, Meleis A.E, Farghaly EF, Solaiman A. Histological study of the possible protective effect of pomegranate juice on bisphenol-A induced changes of the caput epididymal epithelium and sperms of adult albino rats. Alexandria Journal of Medicine. 2011; 47: 125-137.

12. Mazroa SA. Effect of bisphenol A on the cauda epididymis of adult male albino rats and the possible protective role of quercetin: a histological and immunohistochemical study. The Egyptian Journal of Histology. 2011; 34: 377-390.

13. Mohamed DA, Arafa MH. Testicular toxic changes induced by bisphenol $\mathrm{A}$ in adult albino rats: a histological, biochemical, and immunohistochemical study. The Egyptian Journal of Histology. 2012; 36: 233-245. 
14. Hegazy R, Hegazy A. Hegazy' Simplified Method of Tissue Processing (Consuming Less Time and Chemicals). Ann. of Int. Med. \& Den. Res. 2015;1(2):57-61.

15. Suvarna SK, Layton C, Bancfort JD, Stevens A. Theory and practice of histological techniques, $7^{\text {th }}$ ed. China: Churchill Livingstone, 2013:

16. Kiernan JA. Histological and Histochemical Methods: Theory and Practice. 4th ed., Bloxham, UK:Scion Publishing Ltd, 2008:

17. Blandau RJ, Jordan FS. Effect of delayed fertilization on development of rat ovum. The American Journal of Anatomy; 1941; 68: 275-291.

18. Bearden HJ, Fuquay J. Applied Animal Reproduction. Reston Virginia: Reston publishing, 1980: P: 158-160.

19. Blazak WF, Treinen KA, Juniewicz, PE. Application of testicular sperm head counts in the assessment of male reproductive toxicity. In: Chapin, R.E. and Heindel, J. (editors). Male Reproductive Toxicology. Volume 3. New York: Academic press, 1993: P: 86-105.

20. Brown JL, Schoenemann HM, Chakraborty PK. Follicular fluid administration delayed, but did not prevent, the hemicastration-induced increase in follicle-stimulating hormone secretion and compensatory testicular hypertrophy in ram lambs. Biology of Reproduction. 1994; 50(1): 44-48.

21. Shata FYH, Eldebaky HAA, Abd El Hameed AR. Effects of Camphor on Hepatic Enzymes, Steroids and Antioxidant Capacity of Male Rats Intoxicated with Atrazine. Middle-East Journal of Scientific Research. 2014; 22 (4): 553-560.

22. Bakare AA, Ademeso MM, Adetunji OA, Alabi OA. Pharmaceutical effluent induced chromosome aberration in rat bone marrow cells Arch. Journal of applied sciences research. 2011; 3(2): 345-352.

23. Inumaru $J$, Nagano $\quad \mathrm{O}$, Takahashi E, Ishimoto $\mathrm{T}$ et al. Molecular mechanisms regulating dissociation of cell-cell junction of epithelial cells by oxidative stress. Genes to Cells. 2009; 14(6): 703-16.

24. Mourad IM, Khadrawy YA. The sensitivity of liver, kidney and testis of rats to oxidative stress induced by different doses of bisphenol A. International Journal of Life science and Pharma Research. 2012; 2(2): L19-L28.

25. Yeung $\mathrm{CH}$, Wang $\mathrm{K}$ and Cooper TG. Why are epididymal tumours so rare? Asian Journal of Andrology. 2012; 14: 465-475

26. Gregory M, Cyr DG. The bloodepididymis barrier and inflammation. Spermatogenesis. 2014; 4(2): e979619.

27. Dube E, Hermo L, Chan, PT, Cyr DG. Alterations in gene expression in the caput epididymides of nonobstructive azoospermic men. Biology of Reproduction. 2008; 78: 342-351.

28. Korah N, Smith CE, D'Azzo A, Mui J, Hermo L. Characterization of cell- and region-specific abnormalities in the epididymis of cathepsin A deficient mice. Molecular Reproduction and Development. 2003; 66(4): 358-73.

29. Hughes D, Mehmet H. Cell Proliferation and Apoptosis. Oxford: Bios Scientific Publisher Limited, 2003: P: 211.

30. Hegazy R, Hegazy A, Ammar M, Salem E. Immunohistochemical measurement and expression of Mcl-1 in infertile testes. Front. Med. 2015:9(3):361-367

31. Kempinas W D-G, Klinefelter GR. Interpreting histopathology in the epididymis. Spermatogenesis. 2014;4(2): e979114.

32. Robaire $B$, syntin $P$, Jervis $K$. the coming age of the epididymis. in: Jegou B Pineau C Saez J (editors).Testis, Epididymis and Technologies in the Year 2000: 11th European Workshop. Germany: SpringerVerlag Berlin Heidlberg; 2000: 229-262.

33. Bradshaw RA. The extracellular matrix in: Bradshaw RA, Stal PD (chief editors). Encyclopedia of Cell Biology. $1^{\text {st }}$ ed., Volume 2. USA: Elsevier Inc, 2016, P: 694.

34. Wei MC, Zong WX, Cheng, EH, Lindsten T, Panoutsakopoulou, V et al. Proapoptotic BAX and BAK: a requisite gateway to mitochondrial dysfunction and death. Science. 2001; 292(5517): 727-30.

35. Lin Y, Sun X, Qiu L, Wei J, Huang Q et al. Exposure to bisphenol $A$ induces dysfunction of insulin secretion and apoptosis through the damage of mitochondria in rat insulinoma (INS-1) cells. Cell Death and Disease. 2013; 4(1): e460. 
36. Haschek WM, Rousseaux, CG and Wallig MA. Fundamentals of Toxicologic Pathology. $2^{\text {nd }}$ ed., Canada: Elsevier Inc, 2010: P: 590.

37. Karnam SS, Ghosh RC, Mondal S, Mondal M. Evaluation of subacute bisphenol-A toxicity on male reproductive system. Veterinary World. 2015; 8(6): 738-744.

38. Siddique RA, Gali JM, Kumar R, Kumar A, Malik PK et al. Sperm abnormalities and DNA fragmentation vis-à-vis mammalian male infertility - a review. Wayamba Journal of Animal Science. 2011; 578X: 174-189.

39. Herath CB, Jin W, Watanabe G, Arai K, Suzuki AK et al. Adverse effects of environmental toxicants, octylphenol and bisphenol A, on male reproductive functions in pubertal rats. Endocrine. 2004; 25: $163-172$.

40. Howdeshell KL, Furr J, Lambright CR, Wilson VS, Ryan BC et al. Gestational and lactational exposure to ethinyl estradiol, but not bisphenol A, decreases androgen- dependent reproductive organ weights and epididymal sperm abundance in the male long evans hooded rat. Toxicological Sciences. 2008; 102: 371-382.

41. Dietrich D, Kriegerp HO. Chapter 6: endocrine disrupting compounds. In: Histological Analysis of Endocrine Disruptive Effects in Small Laboratory Fish. USA: Willey \& Sons, Inc, 2009: 115246.

42. Alkalby JMA. Effect of bisphenol a on thyroid, liver and testicular functions in adult male rats. Basrah journal of veterinary research. 2015; 14(1): 187-206.

43. Boffetta $P$, van der Hel O, Norppa H, Fabianova E, Fucic A et al. Chromosomal Aberrations and Cancer Risk: Results of a Cohort Study from Central Europe. American Journal of Epidemiology. 2005; 165 (1): 36-43. 